Clausthal Royal Mining Academy, Germany. He was one of the first band of students who studied under Archibald Geikie, and at the age of twentythree years he became a member of H.M. Geological Survey. He always regarded it as a privilege that he was sent to the field as a junior member of the staff under Peach and Horne in the survey of the north-west Highlands, and an account of his laboratory experiments illustrating the mode of production of the complicated tectonics of that region is included in their classic memoir. On succeeding to the family estate in 1888 he retired from the Survey after only five years' service, but his interest in geology and geography continued unabated, and he was the author of a long series of geological and geographical papers, many of which were the results of observations made during his frequent and extensive travels.

Cadell's more important publications dealt with the oil-shale field and general geology of West Lothian, and with the geological history of the Forth valley. $\mathrm{He}$ was essentially a practical geologist and took an active part in the development of the coal- and oil-shale fields of West Lothian, and in the reclamation of the muddy foreshore along parts of the Firth of Forth. He was also interested in the exploitation of the coal resources of Spitsbergen.

The various scientific societies in Edinburgh, particularly the Royal Scottish Geographical Society, the Royal Society of Edinburgh, and the Edinburgh Geological Society owe Dr. Cadell a great debt of gratitude for many services rendered and for generous financial support. $\mathrm{He}$ led the life of a country gentleman and became a county magnate, serving in various capacities on the County Council of Linlithgow, and becoming Deputy-Lieutenant. He also served in the 'volunteers' for twenty-four years and retired in 1906 with the rank of Lieut.-Colonel and Hon. Colonel, V.D.

Cadell's services to the University of Edinburgh were many, and special mention may be made of the interest he took in the founding of the chairs of mining and of geography. As a recognition of his scientific attainments and public work he was awarded the honorary degree of LL.D. by the University in 1932.

It is rare to find combined in one personality gifts of such a varied nature, and he will be greatly missed in Edinburgh.

T. J. JEHU.

\section{DR. J. P. VAN DER STOK}

Johannes Paulus van Der StoK was born on January 14, 1851, at Zuilen, near Utrecht. He studied at the University at Utrecht and took his degree of doctor in physics and mathematics in 1874. In 1877 he went to Java as sub-director of the Magnetic and Meteorological Observatory at Batavia, was appointed director in 1882 and retired as such in $\mathbf{1 8 9 9 .}$

Van der Stok's first publications dealt with periods in terrestrial magnetism and meteorology in relation to the sun and moon, and the observatory at Batavia co-operated in many international researches in seismology, terrestrial magnetism and cloud studies. His most important work, however, were his tidal studies, based on Darwin's method. By a skilful arrangement of direct readings of tide gauges at well-chosen hours, and many original methods of discussing the results, he was able to disentangle completely the very complex tidal phenomena in the Archipelago. The results have been published in a series of sixteen papers and in the atlas "Wind, Weather, Tides and Tidal Streams in the East Indian Archipelago". Tide prediction, highly important for shipping especially near Sourabaya, has since been carried out by Van der Stok's methods largely by native assistants.

After his return to Holland, Van der Stok became director of the oceanographical department of the Meteorological Institute at De Bilt and remained so until 1923. There his principal work was the supervision of the publication of oceanographical atlases of the Indian and Atlantic Oceans, but he continued also his tidal work and published an "Elementary Theory of the Tides" with numerous tidal constants for the East Indian Archipelago, which has been translated into German. He also published through the Amsterdam Academy of Sciences many studies in climatology and dynamical meteorology. $\mathrm{He}$ was the first to introduce 'stability' as a numerical indication of the degree of variability in direction of wind- and current-vectors, and one of the first to use and investigate frequency tables and curves in climatology-we need only mention his treatment of tides in the North Sea and of the climate of the North Sea deduced from lightship observations. After several years of illness, borne with exceptional patience and cheerfulness, he died on March 29, 1934, at the age of eighty-three years. Throughout the world his name will be gratefully remembered.

E. van Everdingen.

THE death is announced of Frederick William Christian, anthropologist and explorer, city librarian of Christchurch, New Zealand, which took place at the age of sixty-six years at Wellington, N.Z. F. W. Christian, the son of E. H. Christian, was born at Putney Hill on June 15, 1867, and educated at Eton and Balliol College, Oxford. After taking his degree he became interested in the exploration of the Pacific, and more particularly of the islands of Micronesia. His ethnographical observations in this area were of enduring value and continue to be the best and most authoritative account of some of the lesser-known islands. His best-known and most frequently quoted work is "The Caroline Islands" (1899). He also published "Eastern Pacific Lands" (1910) and a comparative study of a number of the Oceanic languages. $\mathrm{He}$ was a frequent contributor to the publications of the Polynesian Society and other scientific journals. 